\title{
Ethnobotany, Pharmacology and Phytochemical Investigations of the Seeds of Pentaclethra macrophylla Benth (Mimosaceae)
}

\author{
Pierre V. K. Sinda1, Beaudelaire K. Ponou1, Borice T. Tsafackㄹ, Jonas Kühlborn², \\ Roland T. Tchuenguem ${ }^{3}$, Rémy B. Teponno ${ }^{1 *}$, Jean P. Dzoyem ${ }^{3}$, Till Opatz ${ }^{2}$, Léon A. Tapondjou ${ }^{*}$ \\ ${ }^{1}$ Research Unit of Environmental and Applied Chemistry, Department of Chemistry, Faculty of Science, University of Dschang, \\ Dschang, Cameroon \\ ${ }^{2}$ Department of Chemistry, Johannes Gutenberg University, Duesbergweg, Mainz, Germany \\ ${ }^{3}$ Research Unit of Microbiology and Antimicrobial Substances, Department of Biochemistry, Faculty of Science, University of \\ Dschang, Dschang, Cameroon \\ Email: *remyteponno@gmail.com, *tapondjou2001@yahoo.fr
}

How to cite this paper: Sinda, P.V.K., Ponou, B.K., Tsafack, B.T., Kühlborn, J., Tchuenguem, R.T., Teponno, R.B., Dzoyem, J.P., Opatz, T. and Tapondjou, L.A. (2021) Ethnobotany, Pharmacology and Phytochemical Investigations of the Seeds of Pentaclethra macrophylla Benth (Mimosaceae). Advances in Biological Chemistry, 11, 126-141. https://doi.org/10.4236/abc.2021.113009

Received: May 8, 2021

Accepted: June 14, 2021

Published: June 17, 2021

Copyright $\odot 2021$ by author(s) and Scientific Research Publishing Inc. This work is licensed under the Creative Commons Attribution International License (CC BY 4.0).

http://creativecommons.org/licenses/by/4.0/ (c) (i) Open Access

\begin{abstract}
Phytochemical investigation of the seeds of Pentaclethra macrophylla led to the isolation of a mixture of two new aromatic monoterpene glycosides, pentamacrophylloside A (1a) and pentamacrophylloside B (1b), together with six known secondary metabolites: Comososide (2), secopentaclethroside (3), caffeoylputrescine (4), $\beta$-sitosterol-3- $O$ - $\beta$-D-glucopyranoside (5),

2-hydroxymethyl-5-(2-hydroxypropan-2-yl)phenol (6), and sucrose (7). Their structures were elucidated mainly by extensive spectroscopic analysis (1D and 2D NMR), high-resolution mass spectrometry and by comparison of their spectral data with those of related compounds. The extracts and compounds 3 and 4 were screened for their antimicrobial activity. The $n-\mathrm{BuOH}$ fraction showed a weak effect against three microbial strains: Candida albicans (MIC: $256 \mu \mathrm{g} / \mathrm{mL}$ ), Enterococcus faecalis (MIC: $512 \mu \mathrm{g} / \mathrm{mL}$ ), and Proteus mirabilis (MIC: $512 \mu \mathrm{g} / \mathrm{mL}$ ) while no significant inhibition was observed for pure compounds when compared to ketoconazole and ciprofloxacin used as references. Furthermore, the ethnobotany and pharmacology of this plant are reviewed, and the chemophenetic significance of the isolation of the above secondary metabolites is discussed. This is the first report on the isolation of aromatic monoterpenoids from a plant of the genus Pentaclethra.
\end{abstract}

\section{Keywords}

Pentaclethra macrophylla, Ethnobotany, Pharmacology, Aromatic Monoterpenoids, Chemophenetic Significance, Antimicrobial Activity 


\section{Introduction}

Plants have been used in traditional medicine worldwide for the treatment of diseases and many drugs have been developed from their chemical constituents. This is also the case for species of the genus Pentaclethra belonging to the Mimosaceae family comprising plants widely distributed in Africa and South America [1]. This genus contains only three species including Pentaclethra eetveldeana, Pentaclethra macroloba and Pentaclethra macrophylla [2]. Pentaclethra macrophylla can have $21 \mathrm{~m}$ in high and approximatively $60 \mathrm{~cm}$ in diameter and is known as the African oil bean tree. It is mostly found in the forests of the Eastern and Western regions of Nigeria and in some regions of Senegal, Angola, Cameroon and Gabon [3]. Plants of the genus Pentaclethra have an ethnopharmacological background in the African traditional medicine where they are used for the treatment of several diseases such as itch, gonorrhoea, diarrhoea, small pox and infertility [4] [5]. Previous phytochemical studies revealed that plants of the genus Pentaclethra are a rich source of secondary metabolites such as saponins, tannins, alkaloids, flavonoids and monoglycerides [6]. Previous chemical investigation of the seeds of $P$. macrophylla led to the isolation of two diterpernoids, secopentaclethrolide and secopentaclethroside; one alkaloid, caffeoylputrescine and one glycerol derivative, glyceryl monotetracosanoate [7]. Recent pharmacological studies on stem bark, and leaves of this plant revealed its antinociceptive [4], antidiarrheal [8], antimicrobial [9] [10], and hepatoprotective [11] activities. In the course of our continuing search for bioactive secondary metabolites from medicinal plants growing in Cameroon [12] [13] [14], we undertook the phytochemical investigation of the $n$-butanol soluble fraction from the ethanol extract of the seeds of $P$. macrophylla leading to the isolation and structure elucidation of an inseparable mixture of two new aromatic monoterpene glycosides together with six known compounds (Figure 1).

\section{Ethnobotanical and Traditional Uses of Pentaclethra macrophylla}

Pentaclethra macrophylla popularly known as African oil bean is a member of the Leguminosae family. A decoction of fermented extract of seeds of this plant has been known to be effective in the management of malnutrition, gastrointestinal disorders and dental caries [15]. The bark, fruits, seeds and the leaves are used as anthelmintics, for gonorrhea, convulsion, and as analgesic [16] [17] [18]. The extracted oil from the seeds is used as remedy against pruritus, worms, and dysentery [19] [20] [21]. Moreover, the seeds are used for the treatment of diabetes in Nigerian folk medicine [22]. In addition, it is used for the treatment of itching and pain in animals and in man [23].

\section{Pharmacological Properties of Pentaclethra macrophylla Seeds}

\subsection{Antiulcerogenic Activity}

The antiulcerogenic potentials of aqueous extract of fermented $P$. macrophylla 
<smiles>CC(O)(CC(=O)O)CC(=O)OCc1ccc(C(C)(C)O)cc1OC(O)CC(O)C(O)CO</smiles>

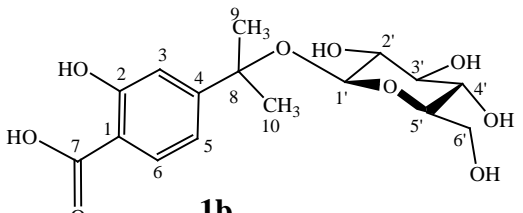

$1 \mathbf{b}$<smiles>Cc1ccc(C(C)(C)O)cc1OC1OC(O)C(O)C(O)C1O</smiles>

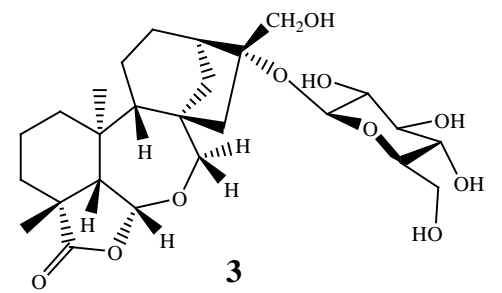<smiles>NCCCCNC(=O)/C=C/c1ccc(O)c(O)c1</smiles>

4<smiles>CC(C)(O)c1ccc(CO)c(O)c1</smiles>

6

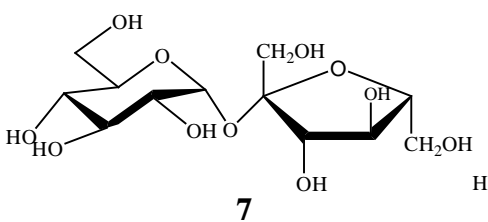

7<smiles>CC[C@H](OCCO)O[C@H]1CC[C@@]2(C)C(=CCC3C4CC[C@H]([C@H](C)CC[C@@H](CC)C(C)C)[C@]4(C)CCC32)C1</smiles>

Figure 1. Structures of compounds (1-7).

seeds were studied using acetic acid, aspirin, ethanol, indomethacin and pyloric ligation of ethanol induced ulcer models at the doses of 400 and $800 \mathrm{mg} / \mathrm{kg}$ body weight. Omeprazole at $5 \mathrm{mg} / \mathrm{kg}$ was used as a standard reference drug. The different doses of the extract and the reference drug decreased significantly ( $\mathrm{p}<$ 0.05 ) the ulcer parameters in a dose-dependent manner in all the ulcer models. Moreover the result of the acute toxicity test showed that the extract did not cause any mortality of the animals possessing $5000 \mathrm{mg} / \mathrm{kg}$ body weight. Therefore, the enhanced cessation of gastric erosions could be attributed to the synergistic role of biochemicals and microbiomes residents in fermented aqueous extract of $P$. macrophylla seeds; suggesting that a decoction of fermented aqueous extract of seeds of this plant could be employed in ethnomedicine for the treatment of peptic ulcer [15].

\subsection{Antiinflammatory and Analgesic Activities}

The leaves and seeds of $P$. macrophylla extracts were tested for analgesic and anti-inflammatory activities using mice with in-vivo and in-vitro experimental models. The extracts at 30 and $60 \mathrm{mg} / \mathrm{kg}$ exhibited analgesic activity and anti-inflammatory property using the flick and hot plate tests, acetic acid induced writhing test; and leucocyte counts, pulmonary oedema and oedema paw of mice in a dose-dependent manner. This result therefore explains and justifies the ethnomedical uses of seeds of $P$. macrophylla in the treatment of itching (inflammatory response) and pain in animals and in man [23]. 


\subsection{Antimicrobial Activity}

The antimicrobial efficacy of the ethanol, methanol and water extracts of $P$. macrophylla seeds was evaluated against seven selected pathogens including Escherichia coli, Staphylococcus aureus, Pseudomonas aeruginosa, Klebsiella species, Salmonella typhi, Aspergillus niger and Candida albicans using paper disc and hole diffusion methods. The results showed that the growths of test organisms were inhibited by extracts used and the minimum inhibitory concentration of the extracts ranges between $62.5-250 \mathrm{mg} / \mathrm{ml}$ on the tested isolates. However, the antimicrobial potency of $P$. macrophylla seeds was more prominent against bacterial isolates than fungal isolates [24].

\subsection{Antioxidant Activity}

The antioxidant capacity of the extracts from three samples (raw, dried and autoclaved) of $P$. macrophylla seeds oil was evaluated using

2,2-diphenyl-1-picryphydrazyl (DPPH). For each sample three different solvents were used for extraction (70\% ethanol, $80 \%$ acetone and acidic $70 \%$ acetone). Globally the $70 \%$ ethanol extracted samples showed the greatest antioxidant activity in the DPPH free radical assay [25].

\subsection{Anti-Hyperlipidemic Activity}

The antihyperlipidemic effects of the $P$. macrophylla seeds in high fat diet and streptozotocin-induced diabetic wistar rats were evaluated. Blood glucose and Lipid prolife of animals were analyzed 6 days after STZ injection and feeding to confirm hyperlipidemia and hyperglycemia. 50\% rat feed was substituted with $50 \%$ of the various processed $P$. macrophylla seeds (raw, 1st cooking, 2nd cooking, fermented and fermented and salted) and used to feed the animals [22]. Metformin was administered daily by intra-gastric gavages for 2, 4, 6 and 8 weeks. Treatment of high fat diet and streptozotocin-induced diabetic rats with various processed $P$. macrophylla seeds over a period of 8 weeks significantly $(\mathrm{p}<0.05)$ reduced the levels of plasma, total cholesterol, triglycerides and LDL-cholesterol and increased HDL-cholesterol compared to rats not feed with various processed $P$. macrophylla seeds. The various processed $P$. macrophylla seeds also exhibited hypolipidemic activities in high fat diet and streptozotocin-induced diabetic wistar rats for the 8-weeks of treatment. They could be used as source of functional foods providing essential micronutrient preventing progression to cardiovascular diseases [22].

\section{Materials and Methods}

\subsection{General Experimental Procedures}

Melting points were recorded on SMP20 apparatus. ${ }^{1} \mathrm{H}$ and ${ }^{13} \mathrm{C}$ NMR, COSY, HSQC and HMBC spectra were performed in deuterated solvents $\left(\mathrm{CD}_{3} \mathrm{OD}\right.$; DMSO- $d_{6}$ ) on a Bruker AVANCE 500 and 600 spectrometers (Bruker, Germany) at $500 \mathrm{MHz} / 125 \mathrm{MHz}$ and $600 \mathrm{MHz} / 150 \mathrm{MHz}$. All chemical shifts ( $\delta$ ) are 
given in ppm units with reference to tetramethylsilane (TMS) as internal standard, while the coupling constants (J values) are given in Hertz (Hz). Positive ion mode ESI mass spectra were carried out on an Agilent 6210 ESI-TOF mass spectrometer (Agilent Technologies, Santa Clara, CA, USA) and on an Agilent Technologies LC/MSD Trap SL (G2445D SL). Purification of fractions and sub-fractions were carried out by column chromatography, Medium-Pressure Liquid Chromatography (MPLC) system [Büchi pump manager C-615, Büchi pump module C-605, Büchi column $(460 \times 15 \mathrm{~mm}$ and $230 \times 15 \mathrm{~mm})]$ using silica gel $60(0.006-0.035 \mathrm{~mm}, 0.063-0.200 \mathrm{~mm}$ and $0.04-0.063 \mathrm{~mm})$ and sephadex LH-20. The following solvent systems were used: $\mathrm{MeOH}$ for Sephadex column chromatography, mixtures of Hexane-EtOAc, EtOAc-MeOH and EtOAc-MeOH- $\mathrm{H}_{2} \mathrm{O}$ for silica gel column chromatography, EtOAc-MeOH and EtOAc- $\mathrm{MeOH}-\mathrm{H}_{2} \mathrm{O}$ for MPLC. TLC was carried out on precoated silica gel 60 F254 (Merck) plates developed with Hexane-EtOAc, EtOAc-MeOH and EtOAc- $\mathrm{MeOH}-\mathrm{H}_{2} \mathrm{O}$. The spots were visualized under UV light (254 and $365 \mathrm{~nm}$ ) of lamp multiband (Model UVGL-58 Upland CA 91786, U.S.A) and by spraying with $10 \% \mathrm{H}_{2} \mathrm{SO}_{4}$ followed by heating for $10 \mathrm{~min}$.

\subsection{Plant Material}

The seeds of Pentaclethra macrophylla were collected in Lo'Obiyeng village (with the location $2^{\circ} 57^{\prime} 35^{\prime \prime N}, 11^{\circ} 7^{\prime} 23 " E$ ), Mvilla division, South Region of Cameroon, in June 2016. The plant material was identified by Mr NANA Victor, botanist at the Cameroon National Herbarium, Yaoundé (Cameroon) in comparison with a voucher specimen deposited on number 30002/HNC.

\subsection{Extraction and Isolation}

The seeds of $P$. macrophylla were air-dried, ground to give $5 \mathrm{Kg}$ of powder. This powder was extracted by maceration with $8 \mathrm{~L}$ of ethanol (95\%) at room temperature three times (each time for $24 \mathrm{~h}$ ). After filtration, the solvent was removed by evaporation under reduced pressure to yield a crude ethanol extract (420 g). Part of this extract $(400 \mathrm{~g})$ was suspended in distilled water $(500 \mathrm{~mL})$ and successively extracted with ethyl acetate $(800 \mathrm{~mL})$ and $n$-butanol $(750 \mathrm{~mL})$. The resulting soluble fractions were concentrated to dryness under reduced pressure to give the ethyl acetate $(55 \mathrm{~g})$ and $n$-butanol $(49 \mathrm{~g})$ fractions respectively. Part of the $n$-butanol fraction ( $45 \mathrm{~g}$ ) was submitted to silica gel column chromatography, using EtOAc and a gradient of $\mathrm{MeOH}$ in EtOAc ranging from (1:0) to (1:1) to afford three main sub-fractions (A-C). Recrystallization and filtration of sub-fraction A ( $1 \mathrm{~g})$ yielded compound $5(100 \mathrm{mg})$ and the resulting filtrate was chromatographed on silica gel column using isocratic elution with EtOAc to give two sub-fractions A1 and A2. Sub-fraction A1 ( $0.3 \mathrm{~g})$ was chromatographed over silica gel column eluted by EtOAc to afford compound $6(15 \mathrm{mg})$. The sub-fraction A2 $(0.2 \mathrm{~g})$ was also subjected to silica gel column chromatography using EtOAc as eluent, yielding compound 2 (20 mg). Sub-fraction B (2 g) 
was chromatographed on silica gel column eluted with a mixture of EtOAc$\mathrm{MeOH}$ (19:1) to yield a mixture of white powder which was further purified by Medium Pressure Liquid Chromatography (MPLC) on normal phase (silica gel: $6.3-35 \mu \mathrm{m})$ eluted with EtOAc-MeOH (98:2) to give compound $3(20 \mathrm{mg})$. Sub-fraction $\mathrm{C}(8 \mathrm{~g})$ was submitted to silica gel column chromatography eluted with EtOAc- $\mathrm{MeOH}-\mathrm{H}_{2} \mathrm{O}$ (8:2:1) to afford three sub-fractions C1-C3. Sub-fraction C3 (500 mg) was purified by MPLC on normal phase, eluted with mixture of EtOAc- $\mathrm{MeOH}-\mathrm{H}_{2} \mathrm{O}$ (8:1.8:0.2) to yield compound 7 (15 mg) and compound 1 (20 mg) which was finally revealed as a mixture of two inseparable compounds (1a and $1 \mathrm{~b}$ ) after using several purification techniques. Sub-fraction C2 (2.5 g) was recrystallized several times with EtOAc-MeOH (80-20) to give $600 \mathrm{mg}$ of compound 4.

\subsection{Methodology of Antimicrobial Assay}

The antimicrobial assay of extracts and some compounds was performed using a microdilution method [26] to determine their minimum inhibitory concentrations (MIC) against five bacterial strains (Staphylococcus aureus (ATCC 1026), Enterococcus faecalis (ATCC 29212), Escherichia coli (ATCC 25922), Pseudomonas aeruginosa (ATCC74117), and one isolate: Proteus mirabilis) and three yeasts (One strain of Candida albicans ATCC 9028, and two isolates: Candida glabrata and Candida dubiniensis). Ciprofloxacin and ketoconazole were used as references. Briefly, the test sample and the selected antibiotic were dissolved in dimethylsulfoxide-Mueller Hinton broth (DMSO-MHB) and dimethylsulfoxide-Sabouraud Dextrose broth (DMSO-SDB). The solution obtained was then added to MHB and SDB and serially diluted twofold in 96-well microplates to give a final concentration range of 2 to $1024 \mu \mathrm{g} / \mathrm{mL}$ for extracts and from 0.5 $128 \mu \mathrm{g} / \mathrm{mL}$ for pure compounds and references. One hundred microliters of inoculums prepared in MHB at a concentration of $1.5 \times 10^{6} \mathrm{CFU} / \mathrm{mL}$ were then added, even for SDB. The plates were covered with a sterile plate sealer and then agitated with a shaker to mix the contents of the wells and incubated at $37^{\circ} \mathrm{C}$. The final concentration of DMSO was less than $2.5 \%$, and DMSO did not affect the microbial growth. Wells containing only MHB or SDB, $100 \mu \mathrm{L}$ of any inoculum and DMSO at a final concentration of $2.5 \%$ served as the negative control. The MICs of samples were detected after $18 \mathrm{~h}$, following addition of $40 \mu \mathrm{L}$ of INT $0.2 \mathrm{mg} / \mathrm{mL}$ and incubation at $37^{\circ} \mathrm{C}$ for $30 \mathrm{~min}$. Viable bacteria reduced the yellow dye to pink. The MIC was defined as the lowest sample concentration that prevented the colour change and that resulted in the complete inhibition of microbial growth. Each assay was repeated three times independently. For the determination of the minimum bactericidal concentration (MBC), a portion of the liquid $(5 \mu \mathrm{L})$ from each well that showed no change in colour was plated on MHB and incubated at $37^{\circ} \mathrm{C}$ for $24 \mathrm{~h}$. The lowest concentration that yielded no growth after this sub-culturing was taken as the MBC. Even, the low concentrations which induced an absence of turbidity at the bottom of the well after incu- 
bation were noted as the MFC.

\section{Results and Discussion}

The structures of compounds $\mathbf{2}-\mathbf{7}$ were determined on the basis of their spectroscopic and mass spectrometric data in comparison with those reported in the literature as comososide (2) [27], secopentaclethroside (3) [7], caffeoylputrescine (4) [28] [29], $\beta$-sitosterol-3- $O$ - $\beta$-D-glucopyranoside (5) [30], 2-hydroxymethyl5-(2-hydroxypropan-2-yl)phenol (6) [31], and sucrose (7) [32].

Compound 1 was obtained as colorless oil. Despite the apparent homogeneity of its spot on TLC, it was deduced to be a mixture of two compounds from its spectroscopic analysis. After repeated column chromatography and MPLC separation using different adsorbents (silica gel, Sephadex LH-20, RP-18) no separation was attempted. The negative mode HRESI-MS showed two quasi-molecular ions peaks at $\mathrm{m} / \mathrm{Z} 487.1841[\mathrm{M}-\mathrm{H}]^{-}$(calcd. for $\mathrm{C}_{22} \mathrm{H}_{31} \mathrm{O}_{12}: 487.1821$ ) and at $\mathrm{m} / \mathrm{Z}$ $357.1202[\mathrm{M}-\mathrm{H}]^{-}$(calcd. for $\mathrm{C}_{16} \mathrm{H}_{21} \mathrm{O}_{9}$ : 357.1191) corresponding to the molecular formulas of $\mathrm{C}_{22} \mathrm{H}_{32} \mathrm{O}_{12}$ and $\mathrm{C}_{16} \mathrm{H}_{22} \mathrm{O}_{9}$ for compounds $1 \mathrm{a}$ and $\mathbf{1 b}$, respectively. This was also confirmed by the positive mode HRESI-MS which showed two ion clusters at $\mathrm{m} / \mathrm{z} 511.1759[\mathrm{M}+\mathrm{Na}]^{+}$(calcd. for $\mathrm{C}_{22} \mathrm{H}_{32} \mathrm{NaO}_{12}: 511.1786$ corresponding to $\mathrm{C}_{22} \mathrm{H}_{32} \mathrm{O}_{12}$ ) and at $\mathrm{m} / \mathrm{z} 381.1157[\mathrm{M}+\mathrm{Na}]^{+}$(calcd. for $\mathrm{C}_{16} \mathrm{H}_{22} \mathrm{NaO}_{9}$ : 381.1156 corresponding to $\mathrm{C}_{16} \mathrm{H}_{22} \mathrm{O}_{9}$ ). The ${ }^{1} \mathrm{H}-\mathrm{NMR}$ spectrum showed signals of two ABX-spin systems of aromatic protons at $\delta_{\mathrm{H}} 7.32(d, J=$ $\left.8.0 \mathrm{~Hz}, \mathrm{H}_{1 \mathrm{a}}-6\right), 7.16\left(d d, J=1.5 ; 8.0 \mathrm{~Hz}, \mathrm{H}_{1 \mathrm{a}}-5\right), 7.37\left(d, J=1.5 \mathrm{~Hz}, \mathrm{H}_{1 \mathrm{a}}-3\right)$ and at $\delta_{\mathrm{H}} 7.77\left(d, J=8.0 \mathrm{~Hz}, \mathrm{H}_{1 \mathrm{~b}}-6\right), 7.07\left(d d, J=1.6 ; 8.0 \mathrm{~Hz}, \mathrm{H}_{1 \mathrm{~b}}-5\right)$ and $7.09(d, J=1.6$ $\left.\mathrm{Hz}, \mathrm{H}_{1 \mathrm{~b}}-3\right)$, characteristic of two 1,2,4-trisubstituted phenyl rings [31]. Signals of two pairs of singlets at $\delta_{\mathrm{H}} 1.58\left(\mathrm{H}_{1 \mathrm{~b}}-9\right), 1.68\left(\mathrm{H}_{1 \mathrm{~b}}-10\right)$, and $1.54\left(s, \mathrm{H}_{1 \mathrm{~b}}-9 / \mathrm{H}_{1 \mathrm{~b}}-10\right)$ assignable to four methyl groups are also found, suggesting the presence of two isopropanolic hydroxyl groups [33]. The presence of two oxygenated methylene protons was evidenced by signals at $\delta_{\mathrm{H}} 5.28\left(d, J=12.4 \mathrm{~Hz}, \mathrm{H}_{1 \mathrm{a}}-7 \mathrm{a}\right)$ and $5.23(d, J$ $\left.=12.4 \mathrm{~Hz}, \mathrm{H}_{1 \mathrm{a}}-7 \mathrm{~b}\right)$. This spectrum also showed two anomeric protons at $\delta_{\mathrm{H}} 4.93$ (o) and $4.35\left(d ; J=7.6 \mathrm{~Hz} ; \mathrm{H}_{1 \mathrm{~b}}-1^{\prime}\right)$ suggesting the presence of two $\beta$-glucopyranosyl moieties [34] (Table 1). The above data suggested that, the aglycone parts of the two aromatic compounds are derivatives of 2-hydroxymethyl-5-(2-hydroxypropan-2-yl)-phenol [27] [31]. The ${ }^{13} \mathrm{C}$ NMR spectrum exhibited signals for two pairs of methyl groups at $\delta_{\mathrm{C}} 30.4\left(\mathrm{C}_{\mathrm{la}}-9\right), 30.3$ $\left(\mathrm{C}_{1 \mathrm{a}}-10\right)$ and $29.4\left(\mathrm{C}_{1 \mathrm{~b}}-9\right), 26.8\left(\mathrm{C}_{1 \mathrm{~b}}-10\right)$; two oxygenated aromatic carbons at $\delta_{\mathrm{C}}$ $155.3\left(\mathrm{C}_{1 \mathrm{a}}-2\right)$ and at $\delta_{\mathrm{C}} 161.0\left(\mathrm{C}_{1 \mathrm{~b}}-2\right)$; four substituted aromatic carbons $\left[\delta_{\mathrm{C}} 113.5\right.$ $\left.\left(\mathrm{C}_{1 \mathrm{~b}}-1\right), 123.5\left(\mathrm{C}_{\mathrm{la}}-1\right), 151.6\left(\mathrm{C}_{1 \mathrm{a}}-4\right), 151.9\left(\mathrm{C}_{1 \mathrm{~b}}-4\right)\right]$; six methine aromatic carbons [ $\delta_{\mathrm{C}} 129.0\left(\mathrm{C}_{1 \mathrm{a}}-6\right), 118.3\left(\mathrm{C}_{1 \mathrm{a}}-5\right), 111.9\left(\mathrm{C}_{1 \mathrm{a}}-3\right)$ and $129.7\left(\mathrm{C}_{1 \mathrm{~b}}-6\right), 116.7\left(\mathrm{C}_{1 \mathrm{~b}}-5\right)$, $114.0\left(\mathrm{C}_{1 \mathrm{~b}}-3\right)$ ]; two oxygenated $\mathrm{sp}^{3}$ quaternary carbons at $\delta_{\mathrm{C}} 71.6\left(\mathrm{C}_{1 \mathrm{a}}-8\right)$ and at $\delta_{\mathrm{C}} 78.6\left(\mathrm{C}_{1 \mathrm{~b}}-9\right)$ and two anomeric carbons at $\delta_{\mathrm{C}} 101.5\left(\mathrm{C}_{1 \mathrm{a}}-1^{\prime}\right)$ and at $\delta_{\mathrm{C}} 98.3$ $\left(\mathrm{C}_{1 \mathrm{~b}}-1\right.$ '). From the ${ }^{1} \mathrm{H}$ and ${ }^{13} \mathrm{C}$ NMR data (Table 1$)$, it was evident that 1 was a mixture of two glycosylated aromatic monoterpenoids. The difference between the two aglycone parts was the presence of only one oxymethylene group at $\delta_{\mathrm{C}} 61.3$ $\left(\mathrm{C}_{1 \mathrm{a}}-7\right)$ in compound $1 \mathrm{a}$ and a carboxyl group at $\delta_{\mathrm{C}} 174.5\left(\mathrm{C}_{1 \mathrm{~b}}-7\right)$ in compound 
Table 1. ${ }^{1} \mathrm{H}$ NMR (600 MHz) and ${ }^{13} \mathrm{C}$ NMR (150 MHz) data of compounds $1 \mathbf{a}$ and $\mathbf{1 b}$, $\mathrm{CD}_{3} \mathrm{OD}, \delta$ in ppm multiplicity and $J(\mathrm{~Hz})$ in brackets.

\begin{tabular}{|c|c|c|c|c|}
\hline \multirow{2}{*}{ Position } & \multicolumn{2}{|l|}{ 1a } & \multicolumn{2}{|l|}{$1 \mathrm{~b}$} \\
\hline & $\delta_{\mathrm{H}}$ & $\delta_{\mathrm{C}}$ & $\delta_{\mathrm{H}}$ & $\delta_{\mathrm{C}}$ \\
\hline 1 & & 123.5 & & 113.5 \\
\hline 2 & & 155.3 & & 161.0 \\
\hline 3 & $7.37(\mathrm{~d}, J=1.5 \mathrm{~Hz})$ & 111.9 & $7.09(\mathrm{~d}, J=1.6 \mathrm{~Hz})$ & 114.0 \\
\hline 4 & & 151.6 & & 151.9 \\
\hline 5 & $7.16(\mathrm{dd}, J=8.0,1.5 \mathrm{~Hz})$ & 118.3 & $7.07(\mathrm{dd}, J=8.0,1.6 \mathrm{~Hz})$ & 116.7 \\
\hline 6 & $7.32(\mathrm{~d}, J=8.0 \mathrm{~Hz})$ & 129.0 & $7.77(\mathrm{~d}, J=8.0 \mathrm{~Hz})$ & 129.7 \\
\hline 7 & $\begin{array}{l}5.23(\mathrm{~d}, J=12.4 \mathrm{~Hz}) \\
5.28(\mathrm{~d}, J=12.4 \mathrm{~Hz})\end{array}$ & 61.3 & & 174.5 \\
\hline 8 & & 71.6 & & 78.6 \\
\hline 9 & $1.54(\mathrm{~s})$ & 30.4 & $1.58(\mathrm{~s})$ & 29.4 \\
\hline 10 & $1.54(\mathrm{~s})$ & 30.3 & $1.68(\mathrm{~s})$ & 26.8 \\
\hline $1^{\prime}$ & $4.93(0)$ & 101.5 & $4.35(\mathrm{~d}, J=7.6 \mathrm{~Hz})$ & 98.3 \\
\hline $2^{\prime}$ & 3.51 & 73.5 & 3.24 & 74.0 \\
\hline $3^{\prime}$ & 3.29 & 76.9 & 3.46 & 76.7 \\
\hline $4^{\prime}$ & 3.42 & 70.0 & 3.30 & 70.3 \\
\hline $5^{\prime}$ & 3.46 & 76.6 & 3.12 & 76.2 \\
\hline $6^{\prime}$ & $\begin{array}{l}3.78(\mathrm{dd}, 11.9,2.4) \\
3.62(\mathrm{dd}, 11.9,5.7)\end{array}$ & 61.2 & $\begin{array}{l}3.92(\mathrm{dd}, 12.1,2.2) \\
3.71(\mathrm{dd}, 12.1,5.6)\end{array}$ & 61.1 \\
\hline $1 "$ & & 171.3 & & \\
\hline $2 "$ & $2.70(\mathrm{~s})$ & 45.3 & & \\
\hline $3 "$ & & 69.5 & & \\
\hline $4 "$ & $\begin{array}{l}2.58(\mathrm{~d}, J=12.6) \\
2.63(\mathrm{~d}, J=15.6)\end{array}$ & 45.3 & & \\
\hline $5 "$ & & 175.2 & & \\
\hline $6 "$ & $1.38(\mathrm{~s})$ & 26.4 & & \\
\hline
\end{tabular}

O: Overlapped signal.

1b. The position of this carboxyl group was evidenced by the HMBC correlation depicted between the signal at $\delta_{\mathrm{H}} 7.77\left(\mathrm{~d}, J=8.0 \mathrm{~Hz}, \mathrm{H}_{1 \mathrm{~b}}-6\right)$ and $\mathrm{C}_{1 \mathrm{~b}}-7\left(\delta_{\mathrm{C}} 174.5\right)$. The different linkage sites of the sugar moieties to the aglycones were determined by the HMBC cross-peak correlations depicted between the anomeric protons at $\delta_{\mathrm{H}} 4.93\left(\mathrm{H}_{1 \mathrm{a}}-1^{\prime}\right), 4.35\left(\mathrm{H}_{1 \mathrm{~b}}-1^{\prime}\right)$ and carbons at $\delta_{\mathrm{C}} 155.3\left(\mathrm{C}_{1 \mathrm{a}}-2\right)$ and 78.6 $\left(\mathrm{C}_{1 \mathrm{~b}}-8\right)$, respectively (Figure 2$)$. Additionally, the ${ }^{13} \mathrm{C}$ NMR spectrum exhibited six signals including a methyl at $\delta_{\mathrm{C}} 26.4\left(\mathrm{C}_{\mathrm{la}}-6^{\prime \prime}\right)$, two methylene groups at $\delta_{\mathrm{C}}$ $45.3\left(\mathrm{C}_{1 \mathrm{a}}-4 ", \mathrm{C}_{1 \mathrm{a}}-2 "\right)$, an hydroxymethine group at $\delta_{\mathrm{C}} 69.5\left(\mathrm{C}_{1 \mathrm{a}}-3 "\right)$, an ester carbonyl at $\delta_{\mathrm{C}} 171.5\left(\mathrm{C}_{1 \mathrm{a}}-1 "\right)$ as well as a carboxyl group at $\delta_{\mathrm{C}} 175.2\left(\mathrm{C}_{1 \mathrm{a}}-5^{\prime \prime}\right)$ characteristic of a 3-hydroxy-3-methylglutaric acid moiety [35]. The location of 

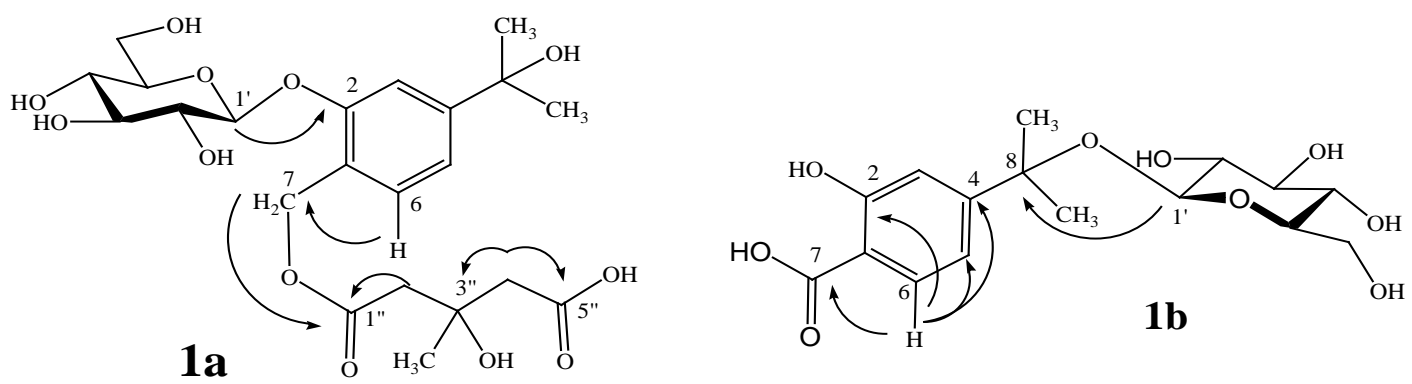

Figure 2. Some important $\mathrm{HMBC}$ correlations of compounds $1 \mathrm{a}$ and $\mathbf{1 b}$.

the 3-hydroxy-3-methylglutaric acid moiety on $\mathrm{C}_{1 \mathrm{a}}-7$ was evidenced from the $\mathrm{HMBC}$ correlation depicted between the proton at $\delta_{\mathrm{H}} 5.23(\mathrm{~d}, J=12.4 \mathrm{~Hz}$, $\left.\mathrm{H}_{1 \mathrm{a}}-7\right)$ and the carbon at $\delta_{\mathrm{C}} 171.3\left(\mathrm{C}_{1 \mathrm{a}}-1\right.$ "). On the basis of the above data, the structures of compounds $1 \mathrm{a}$ and $1 \mathrm{~b}$ were elucidated as two new naturally occurring aromatic monoterpenoids to which the trivial names pentamacrophyllosides A (1a) and B (1b) were given.

Compounds $1 \mathrm{a}$ and $1 \mathrm{~b}$ are aromatic monoterpenoids and could biosynthetically derive from geranyl diphosphate. $\gamma$-terpinene synthase (TvTPS1) which is a member of the monoterpene synthase family could produce $\gamma$-terpinene through cyclization of geranyl diphosphate (Scheme 1). Enzymes such as CYP71D178, CYP71D180 and CYP71D181 belonging to the cytochrome P450 monooxygenases are also involved in further modifications of $\gamma$-terpinene backbone to yield carvacrol (8) [36]. Oxidation of carvacrol could lead to 3-hydroxy- $\alpha, \alpha, 4$-trimethyl benzyl alcohol (9) previously isolated from Lavandula gibsonii [33] and compound 6 [31], respectively. The action of C8-O- $\beta$-D-glucosidase on 6 could yield pentamacrophylloside $\mathrm{B}(1 \mathrm{~b})$. The enzyme $\mathrm{C} 2-O-\beta$-D-glucosidase could then convert 2-hydroxymethyl-5-(2-hydroxypropan-2-yl)phenol (6) to mariaterpenoside A (10) previously isolated from Silybum marianum [31] while the esterification of compound 10 by $\beta$-hydroxy, $\beta$-methylglutaryl-CoA could afford pentamacrophylloside A (1a) (Scheme 1).

Phytochemical studies have previously been carried out only on stem bark and roots of other species of the genus Pentaclethra. Therefore, previous studies on stem bark of $P$. macroloba, and P. eetveldeana led to the isolation of saponins [2] [37] [38], phenolic compounds [39] [40] [41], and fatty acid derivatives [37] [39]. Furthermore, tannins were isolated from stem bark of $P$. macroloba and $P$. macrophylla [39] [40] [41]. Previous pharmacological studies on other species of the genus Pentaclethra particularly on P. macroloba seeds showed its antioxidant, and antimicrobial activities [42] [43]. Compounds 3 and $\mathbf{4}$ were previously isolated from P. macrophylla seeds [7]. Concerning caffeoylputrescine (4), it was the first secondary metabolite isolated from a plant of the genus Pentaclethra [44]. Its isolation from the fruits of $P$. macrophylla during our investigation is not surprising since it was reported that putrescine, spermidine, spermine and their derivatives are the main polyamines present in plants, involved in the regulation of diverse physiological processes such as flower development, embryogenesis, 

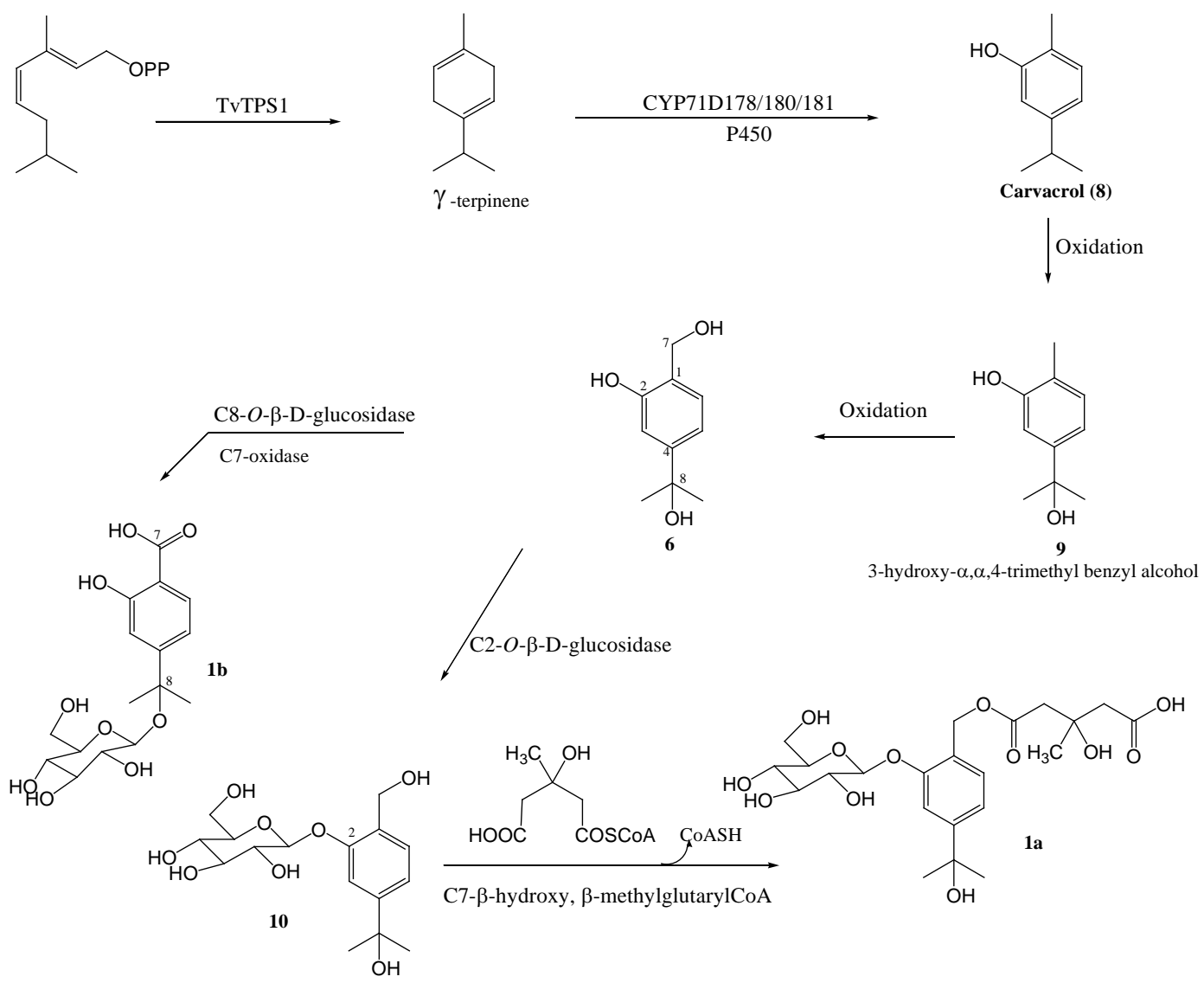

Scheme 1. Proposed biogenetic pathways to the formation of compounds $1 \mathbf{a}$ and $\mathbf{1 b}$ from geranylpyrophosphate.

organogenesis, senescence, and fruit maturation and development [45]. Aromatic monoterpenoids comososide (2) and 2-hydroxymethyl-5-(2-hydroxypropan-2yl)phenol (6) were previously obtained from Curcuma comosa (Zingiberaceae) [27] and Silibum marinum (Asteraceae) [31], respectively. To the best of our knowledge this is the first report on the isolation of this class of compounds from a plant of the genus Pentaclethra.

Although the $n-\mathrm{BuOH}$ extract showed a moderate activity against Candida albicans ATCC 9028, Enterococcus faecalis (ATCC 29212) and Proteus mirabilis with MIC values of 256, 512 and $512 \mu \mathrm{g} / \mathrm{mL}$, respectively (Table 2), the isolated compounds were not active against the five tested bacterial and three yeasts strains compared to ciprofloxacin and ketoconazole used as references, respectively.

\section{Spectroscopic Data of Compounds 1 - 7}

Pentamacrophylloside A (1a): Colorless oil; ${ }^{1} \mathrm{H}$ NMR data $(600 \mathrm{MHz}$, $\mathrm{CD}_{3} \mathrm{OD}$ ) and ${ }^{13} \mathrm{C}$ NMR data $\left(150 \mathrm{MHz}, \mathrm{CD}_{3} \mathrm{OD}\right.$ ) see Table 1; HR-ESI-MS (negative ion mode) $\mathrm{m} / z$ 487.1841 [M-H] ${ }^{-}$(Calcd. for molecular formula $\mathrm{C}_{22} \mathrm{H}_{31} \mathrm{O}_{12}$ : 487.1821) and HR-ESI-MS (positive ion mode) $\mathrm{m} / z$ 511.1759 $[\mathrm{M}+\mathrm{Na}]^{+}$(Calcd for $\mathrm{C}_{22} \mathrm{H}_{32} \mathrm{NaO}_{12}$ : 511.1786). 
Table 2. The minimum inhibitory concentration $(\mu \mathrm{g} / \mathrm{mL})$ of extracts and some isolated compounds against the tested microorganisms.

\begin{tabular}{|c|c|c|c|c|c|c|c|c|c|c|c|c|c|c|c|c|}
\hline \multirow{3}{*}{ Samples } & \multicolumn{16}{|c|}{ Microorganisms } \\
\hline & \multicolumn{2}{|c|}{$\mathrm{Ca}$} & \multicolumn{2}{|c|}{$\mathrm{Cg}$} & \multicolumn{2}{|c|}{$\mathrm{Cd}$} & \multicolumn{2}{|c|}{ Ec } & \multicolumn{2}{|c|}{$\mathrm{Sa}$} & \multicolumn{2}{|c|}{$\mathrm{Pa}$} & \multicolumn{2}{|c|}{ Ef } & \multicolumn{2}{|c|}{$\mathrm{Pm}$} \\
\hline & MIC & MFC & MIC & MFC & MIC & MFC & MIC & MBC & MIC & $\mathrm{MBC}$ & MIC & $\mathrm{MBC}$ & MIC & $\mathrm{MBC}$ & MIC & $\mathrm{MBC}$ \\
\hline Ethanol extract & - & - & - & - & - & - & 1024 & - & - & - & 512 & - & 512 & - & - & - \\
\hline EtOAc fraction & - & - & - & - & - & - & 1024 & - & - & - & 256 & - & 512 & - & - & - \\
\hline$n-\mathrm{BuOH}$ fraction & 256 & - & 1024 & - & 1024 & - & 1024 & - & 1024 & - & 1024 & - & 512 & - & 512 & - \\
\hline 3 & - & - & - & - & - & - & - & - & - & - & & - & - & - & - & - \\
\hline 4 & - & - & - & - & - & - & 1024 & - & - & - & 512 & - & 512 & - & - & - \\
\hline Ketoconazole & 0.5 & 64 & 0.25 & 8 & 8 & 8 & - & - & - & - & - & - & - & - & - & - \\
\hline Ciprofloxacin & - & - & - & - & - & - & 2 & 512 & 1 & 512 & 2 & 8 & 4 & 4 & 2 & 8 \\
\hline
\end{tabular}

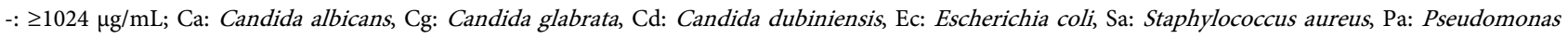
aeruginosa, Ef: Enterococcus faecalis, Pm: Proteus mirabilis.

Pentamacrophylloside B (1b): Colorless oil; ${ }^{1} \mathrm{H}$ NMR data $(600 \mathrm{MHz}$, $\mathrm{CD}_{3} \mathrm{OD}$ ) and ${ }^{13} \mathrm{C}$ NMR data (150 MHz, $\mathrm{CD}_{3} \mathrm{OD}$ ) see Table 1; HR-ES-IMS (negative ion mode) $\mathrm{m} / z$ 357.1202 $[\mathrm{M}-\mathrm{H}]^{-}$(Calcd for $\mathrm{C}_{16} \mathrm{H}_{21} \mathrm{O}_{9}$ : 357.1191) and HR-ESI-MS (positive ion mode) $\mathrm{m} / z 381.1157[\mathrm{M}+\mathrm{Na}]^{+}$(Calcd for $\mathrm{C}_{16} \mathrm{H}_{22} \mathrm{NaO}_{9}$ : 381.1156).

Comososide (2): Yellow oil; ${ }^{1} \mathrm{H}$ NMR $\left(\mathrm{CD}_{3} \mathrm{OD}, 600 \mathrm{MHz}\right): \delta_{\mathrm{H}}=7.27(d, J=$ $1.0 \mathrm{~Hz}, \mathrm{H}-3), 7.09$ (d, J= 7.8 Hz, H-6), 7.04 (dd, $J=1.0,7.8 \mathrm{~Hz}, \mathrm{H}-5), 4.91$ (d, 7.3, H-1'), $3.84\left(d d, J=1.9 ; 12.0 \mathrm{~Hz}, 1 \mathrm{H}, \mathrm{H}-6^{\prime}\right), 3.70(d d, J=12.0 \mathrm{~Hz}, 4.9 \mathrm{~Hz}$, H-6'), 3.49 - 3.50 ( $\left.m, \mathrm{H}-2^{\prime}\right), 3.39$ - 3.40 ( $\left.m, \mathrm{H}-4^{\prime}\right), 3.46$ - 3.47 ( $\left.m, \mathrm{H}-2^{\prime}, \mathrm{H}-5^{\prime}\right)$, $2.26(s, \mathrm{H}-7), 1.53(s, \mathrm{H}-9, \mathrm{H}-10) ;{ }^{13} \mathrm{C} \mathrm{NMR}\left(\mathrm{CD}_{3} \mathrm{OD}, 150 \mathrm{MHz}\right): \delta_{\mathrm{C}}=155.5$ (C-2), 148.6 (C-4), 129.7 (C-6), 125.4 (C-1), 118.0 (C-5), 111.5 (C-3), 101.3 (C-1'), 76.8 (C-5'), 76.7 (C-3'), 73.6 (C-2'), 71.6 (C-8), 70.0 (C-4'), 61,4 (C-6'), 30.5 (C-10), 30.4 (C-9), 14.7 (C-7).

Secopenthaclethroside (3): White amorphous powder; ${ }^{1} \mathrm{H}$ NMR (DMSO- $d_{6}$, $600 \mathrm{MHz}): \delta_{\mathrm{H}}=5.93(d, J=4.3 \mathrm{~Hz}, \mathrm{H}-6), 4.28\left(d, J=7.9, \mathrm{H}-1^{\prime}\right), 3.97(t, J=7.0$ $\mathrm{Hz}, \mathrm{H}-17 \beta), 3.67(d, J=12.4 \mathrm{~Hz}, \mathrm{H}-7 \beta), 3.60-3.64\left(m, \mathrm{H}-6^{\prime}\right), 3.57(t, J=7.4 \mathrm{~Hz}$, $\mathrm{H}-17 \alpha), 3.41(d, J=4.0 \mathrm{~Hz}, \mathrm{H}-7 \alpha), 3.39-3.40\left(m, \mathrm{H}-6^{\prime}\right), 3.15(t, J=8.9 \mathrm{~Hz}$, H-3'), 3.09 - $3.13\left(m, \mathrm{H}-5^{\prime}\right), 3.05\left(t, J=8.8 \mathrm{~Hz}, \mathrm{H}-4^{\prime}\right), 2.95\left(t d, J=8.6,4.3, \mathrm{H}-2^{\prime}\right)$, $2.51-2.53$ ( $m, \mathrm{H}-10), 2.16(d, J=4.2 \mathrm{~Hz}, \mathrm{H}-5), 2.11$ (brs, H-13), $1.92-1.93$ (m, $\mathrm{H}-14), 1.90$ ( $d, J=3.7, \mathrm{H}-3), 1.78-1.82(m, \mathrm{H}-11), 1.65-1.67$ ( $m, \mathrm{H}-1), 1.49$ (o, $\mathrm{H}-12), 1.47$ (o, H-15), 1.39 - 1.42 ( $m, \mathrm{H}-2), 1.23$ - 1.25 (m, H-9), $1.22(s, \mathrm{H}-18)$, $1.12(s, \mathrm{H}-20) ;{ }^{13} \mathrm{C}$ NMR (DMSO- $\left.d_{6}, 150 \mathrm{MHz}\right): \delta_{\mathrm{C}}=178.2(\mathrm{C}-19), 103.0(\mathrm{C}-6)$, 97.3 (C-1'), 89.8 (C-16), 77.3 (C-3'), 77.1 (C-5'), 73.8 (C-2'), 73.7 (C-7), 70.4 (C-4'), 61.9 (C-17), 61.4 (C-6'), 56.8 (C-9), 56.1 (C-5), 49.8 (C-8), 45.6 (C-15), 44.1 (C-4), 42.0 (C-13), 39.2 (C-10), 37.9 (C-14), 36.6 (C-1), 30.4 (C-3), 26.9 (C-18), 26.0 (C-12), 19.6 (C-20), 18.6 (C-11), 18.0 (C-2).

Caffeoylputrescine (4): Yellow amorphous powder; ${ }^{1} \mathrm{H}$ NMR $\left(\mathrm{CD}_{3} \mathrm{OD}, 500\right.$ $\mathrm{MHz}): \delta_{\mathrm{H}}=7.41\left(d, 15.7 \mathrm{~Hz}, \mathrm{H}-7^{\prime}\right), 7.02\left(d, J=2.0, \mathrm{H}-2^{\prime}\right), 6.90(d d, J=8.3,2.0$ 
Hz, H-6'), 6.78 ( $\left.d, J=8.3 \mathrm{~Hz}, \mathrm{H}-5^{\prime}\right), 6.40\left(d, 15.7 \mathrm{~Hz}, \mathrm{H}-8^{\prime}\right), 3.30$ - 3.35 (m, H-2), 2.95 - 2.99 (m, 2H, H-5), 1.67 - $1.74(m, \mathrm{H}-4), 1.62$ - 1.67 (m, H-3); ${ }^{13} \mathrm{C}$ NMR $\left(\mathrm{CD}_{3} \mathrm{OD}, 125 \mathrm{MHz}\right): \delta_{\mathrm{C}}=169.6\left(\mathrm{C}-9^{\prime}\right), 149.8\left(\mathrm{C}-4^{\prime}\right), 146.9\left(\mathrm{C}-3^{\prime}\right), 142.5\left(\mathrm{C}-7^{\prime}\right)$, 128.3 (C-1'), 122.8 (C-6'), 118.4 (C-8'), 116.6 (C-5'), 115.1 (C-2'), 40.6 (C-5), 39.6 (C-2), 27.6 (C-3), 26.0 (C-4).

$\beta$-sitosterol 3-O- $\beta$-D-glucopyranoside (5): White crystals from methanol, $\mathrm{mp}: 290^{\circ} \mathrm{C}-292^{\circ} \mathrm{C}\left[\left(\right.\right.$ lit. $\left.290^{\circ} \mathrm{C}-291^{\circ} \mathrm{C}\right]$ [30].

2-hydroxymethyl-5-(2-hydroxypropan-2-yl)phenol (6): Yellow oil; ${ }^{1} \mathrm{H}$ NMR $\left(\mathrm{CD}_{3} \mathrm{OD}, 500 \mathrm{MHz}\right): \delta_{\mathrm{H}}=7.19(d, 7.8,1 \mathrm{H}, \mathrm{H}-3), 6.94(d, J=1.8, \mathrm{H}-6), 6.91$ $(d d, J=7.8,1.8, \mathrm{H}-4), 4.52(s, \mathrm{H}-7 \mathrm{a} / 7 \mathrm{~b}), 1.50(s, \mathrm{H}-9 / 10) ;{ }^{13} \mathrm{C} \mathrm{NMR}\left(\mathrm{CD}_{3} \mathrm{OD}, 125\right.$ $\mathrm{MHz}): \delta_{\mathrm{C}}=156.1(\mathrm{C}-1), 151.7(\mathrm{C}-5), 129.1(\mathrm{C}-3), 126.6(\mathrm{C}-2), 116.7(\mathrm{C}-4), 112.7$ (C-6), 72.9 (C-8), 61.1 (C-7), 32.0 (C-9/10).

Sucrose 7: White amorphous powder; ${ }^{1} \mathrm{H}$ NMR $\left(\mathrm{CD}_{3} \mathrm{OD}, 600 \mathrm{MHz}\right): \delta_{\mathrm{H}}=$ $5.40(d, J=4.0 \mathrm{~Hz}, \mathrm{H}-1), 4.11\left(d, J=8.3 \mathrm{~Hz}, \mathrm{H}-3^{\prime}\right), 4.04\left(t, J=5.02 \mathrm{~Hz}, \mathrm{H}-4^{\prime}\right)$, 3.80 - 3.84 (m, H-4), 3.79 - 381 (m, H-6), 3.76 - 3.79 (m, H-5), 3.77 - 3.78 (m, H-6'), 3.73 - 3.75 (m, H-6), 3.69 - 3.74 (m, H-3), 3.60 - 3.65 (m, H-1'), 3.42 - 3.45 $(\mathrm{m}, \mathrm{H}-2), 3.37(d d, J=5.0 ; 1.8 \mathrm{~Hz}, \mathrm{H}-5) ;{ }^{13} \mathrm{C} \mathrm{NMR}\left(\mathrm{CD}_{3} \mathrm{OD}, 150 \mathrm{MHz}\right): \delta_{\mathrm{C}}=$ 103.9 (C-2'), 92.2 (C-1), 82.3 (C-5'), 77.8 (C-3'), 74.2 (C-4'), 73.2 (C-3), 72.8 (C-4), 71.8 (C-2), 69.8 (C-5), 62.5 (C-1'), 61.9 (C-6'), 60.7 (C-6).

\section{Conclusion}

In the present study, the seeds of the medicinal plant $P$. macrophylla were investigated, leading to the isolation of a mixture of two new aromatic monoterpene glycosides, pentamacrophylloside A (1a) and pentamacrophylloside B (1b), together with six known compounds. Their structures were elucidated mainly by extensive spectroscopic analysis, high-resolution mass spectrometry and by comparison of their spectral data with those of related compounds. The chemophenetic significance of their isolation was discussed. To the best of our knowledge, this is the first report on the isolation of aromatic monoterpenoids from a plant of the genus Pentaclethra.

\section{Acknowledgements}

The authors are grateful to the Alexander von Humboldt Foundation (AvH), Bonn, Germany for the financial support of this work. We thank the Rhineland Palatinate Centre of Natural Products Research (Mainz, Germany) for funding part of the analytical chemistry involved. We would also thank the Yaoundé-Bielefeld Bilateral Graduate School Natural Products with Antiparasitic and Antibacterial Activities (YaBiNaPa) for recording the mass spectra of some of the isolated compounds.

\section{Conflicts of Interest}

The authors declare no conflicts of interest regarding the publication of this paper. 


\section{References}

[1] Mogomba, G.S. (2013) Ethnoécologie des Mitsogho du Gabon (ethnobotanique et ethnozoologie). Ph.D. Dissertation, University of Lorraine, Lorraine, 1-110.

[2] Viana, F.A., Raimundo, B.-F., Yvone, B.M.P., Manoel, A.N., Gilvandete, M.P.S. and Edson, R.-F. (2004) Triterpenoid Saponins from Stem Bark of Pentaclethra macroloba. Journal of Brazilian Chemical Society, 15, 595-602.

https://doi.org/10.1590/S0103-50532004000400024

[3] Keay, R.W.J., Onochie, C.E.A. and Stanfield, D.P. (1969) Nigerian Trees. Dept of Forest Research, Ibadan, 11, 119-120.

[4] Okunrobo, L.O., Ching, F.P. and Ifiijeh, F. (2009) Antinociceptive Activity of Methanol Extract and Aqueous Fractions of the Stem Bark of Pentaclethra macrophylla (Benth) Mimosaceae. Journal of Medicinal Plants Research, 3, 101-104.

[5] Agbogidi, O. (2010) Response of African Oil Bean (Pentaclethra macrophylla Benth) Seeds to Soils Contaminated with Spent Lubricating Oil. African Journal of Environmental Science and Technology, 4, 492-494.

[6] Oyeleke, G.O., Odedeji, J.O., Ishola, A.D. and Afolabi, O. (2014) Phytochemical Screening and Nutritional Evaluation of Oil Bean (Pentaclethra macrophylla) Seeds. Journal of Environmental Science Toxicology and Food Technology, 8, 14-17. https://doi.org/10.9790/2402-08221417

[7] Folefoc, G.N., Bisseck, J.P., Fomum, Z.T. and Bodo, B. (2004) A New Secokaurane Diterpenoid and Its $O$-Glucoside from Seeds of Pentaclethra macrophylla. Journal of the Cameroon Academy of Science, 4, 227-231.

[8] Akah, P.A., Aguwa, C.N. and Agu, R.U. (1999) Studies on the Antidiarrheal Properties of Pentaclethra macrophylla Leaf Extract. Phytotherapy Research, 13, 292-295. https://doi.org/10.1002/(SICI)1099-1573(199906)13:4<292::AID-PTR415>3.0.CO;2$\underline{\mathrm{N}}$

[9] Ugbogu, O.C. and Akukwe, A.R. (2008) The Antimicrobial Effects of Oil from Pentaclethra macrophylla (Benth.), Chrysophyllum albidum (G Dons) and Persea gratissa (Gaerth. F) on Some Local Clinical Bacteria Isolates. African Journal of Biotechnology, 8, 285-287.

[10] Nneoma, E.A.-E., Chibuike, S.U., Nkoyo, I.N., Alexander, A.N., Uchechukwu, U.N. and Anthony, I.O. (2016) Evaluation of Saponin Extract from Vitex doniana and Pentaclethra macrophylla for Antibacterial Activity. Applied Science, 6, 180. https://doi.org/10.3390/app6060180

[11] Bomgning, K.C.L., Sinda, K.P.V., Ponou, K.B., Fotio, L.A., Tsague, K.M., Tsafack, T.B., Kühlborn, J., Mbuyo-Nguelefack, E.P., Teponno, R.B., Opatz, T., Tapondjou, L.A. and Nguelefack, T.B. (2021) Hepatoprotective Effects of Extracts, Fractions and Compounds from the Stem Bark of Pentaclethra macrophylla Benth: Evidence from in Vitro and in Vivo Studies. Biomedicine \& Pharmacotherapy, 136, 111242. https://doi.org/10.1016/j.biopha.2021.111242

[12] Fouedjou, T.R., Teponno, R.B., Quassinti, L., Bramucci, M., Petrelli, D., Vitali, L.A., Fiorini, D., Tapondjou, A.L. and Barboni, L. (2014) Steroidal Saponins from the Leaves of Cordyline fructicosa (L.) A. Chev. and Their Cytotoxic and Antimicrobial Activity. Phytochemistry Letters, 7, 62-68. https://doi.org/10.1016/j.phytol.2013.10.001

[13] Teponno, R.B., Tanaka, C., Jie, B., Tapondjou, A.L. Miyamoto, T., and Trifasciatosides, A.-J. (2016) Steroidal Saponins from Sansevieria trifasciata Prain. Chemical and Pharmaceutical Bulletin, 64, 1347-1355. https://doi.org/10.1248/cpb.c16-00337 
[14] Ponou, B.K., Teponno, R.B., Tapondjou, A.L., Lacaille-Dubois, M.-A., Quassinti, L., Bramucci, M. and Barboni, L. (2019) Steroidal Saponins from the Aerial Parts of Cordyline fruticosa L. var. Strawberries. Fitoterapia, 134, 454-458. https://doi.org/10.1016/j.fitote.2019.03.019

[15] Ugbogu, A.E., Arunsi, U.O., Uche-Ikonne, O.O., Ude, V.C. and Okezie, E. (2017) Antiulcerogenic Potentials of Fermented Aqueous Extract of Pentaclethra macrophylla (Benth) Seeds. American Journal of Biomedical Research, 5, 57-64. https://doi.org/10.12691/ajbr-5-3-3

[16] Githens, T.S. (1948) African Handbooks-Drug Plants of Africa. University of Pennsylvania Press, Philadelphia, 64.

[17] Bouquet, A., Cave, A. and Paris, R. (1971) Plantes medicinales du Congo-Brazzaville (III) Plantes medicinales et phytotherapie. Tome, 2, 154-158.

[18] Iwu, M.M. (1993) Handbook of African Medicinal Plants. CRC Press, London.

[19] Singha, S.C. (1963) Medicinal Plants of Nigeria, Nigerian College of Arts Science and Technology. 36.

[20] Gugnani, H.C. and Ezenwanze, E.C. (1985) Antibacterial Activity of Extracts of Ginger (Zingiber officinale) and African Oil Bean Seed (Pentaclethra macrophylla). Journal of Communicable Diseases, 17, 233-236.

[21] Kamanzi Atindehou, K., Koné, M., Terreaux, C., Traore, D., Hostettmann, K. and Dosso, M. (2002) Evaluation of the Antimicrobial Potential of Medicinal Plants from the Ivory Coast. Phytotherapy Research, 16, 497-502.

https://doi.org/10.1002/ptr.970

[22] Nwosu, U.C., Essien, E.B. and Ohiri, R.C. (2017) Phytochemical, Mineral Composition and Anti-Hyperlipidemic Effects of Processed Pentaclethra macrophylla Seeds on High Fat Diet and Streptozocin-Induced Diabetic Wistar Rats. International Journal of Agriculture and Earth Science, 3, 31-41. https://doi.org/10.9734/IJBCRR/2017/35235

[23] Okorie, C.C., Oparaocha, E.N.T., Adewunmi, C.O., Iwalewa, E.O. and Omodara, S.K. (2006) Antinociceptive, Anti-Inflammatory and Cytotoxic Activities of Pentaclethra macrophylla Aqueous Extracts in Mice. African Journal of Traditional, Complementary and Alternative Medicines, 3, 44-53. https://doi.org/10.4314/ajtcam.v3i1.31138

[24] Olaitan, J.O., Kareem, S.O. and Dada, S.O. (2009) Antimicrobial Potency of Pentaclethra macrophylla Seed Extract on Seven Selected Pathogens. African Journal of Biomedical Research, 12, 141-144.

[25] Oyinloye, A.M. and Enujiugha, V.N. (2019) Antioxidant Properties of African Oil Bean (Pentaclethra macrophylla Benth) Seed Phenolics as Influenced by Extraction Solvents and Heat Treatments. Applied Tropical Agriculture, 24, 42-48.

[26] Dzoyem, J.P., Tchamgoue, J., Tchouankeu, J.C., Kouam, S.F., Choudhary, M.I. and Bakowsky, U. (2018) Antibacterial Activity and Cytotoxicity of flavonoids Compounds Isolated from Pseudarthria hookeri Wight \& Arn. (Fabaceae). South Africa Journal of Botany, 114, 100-103. https://doi.org/10.1016/j.sajb.2017.11.001

[27] Nakamura, S., Qu, Y., Xu, F., Matsuda, H. and Yoshikawa, M. (2008) Structures of New Monoterpenes from Thai Herbal Medicine Curcuma comosa. Chemical and Pharmaceutical Bulletin, 56, 1604-1606. https://doi.org/10.1248/cpb.56.1604

[28] Mizusaki, S., Tanabe, Y., Noguchi, M. and Tamaki, E. (1971) P-Coumaroylputrescine, Caffeolylputrescine and Ferulylputrescine from Callus Issue Culture of Nicotiana tabacum. Phytochemistry, 10, 1347-1350. 
https://doi.org/10.1016/S0031-9422(00)84339-3

[29] Buta, J.G. and Izac, R.R. (1972) Caffeoyl Putrescine in Nicotiana tabacum. Phytochemistry, 11, 1188-1189. https://doi.org/10.1016/S0031-9422(00)88494-0

[30] Wang, Y., Lai, D., Zhang, Y., Kang, A., Cao, Y. and Sun, W. (2009) Study of Steroidal Saponins in Dioscorea zingiberensis C.H. Wright. Journal of Natural Products, 2, 123-132.

[31] Qin, N.-B., Li, S.-G., Yang, X.-Y., Gong, C., Zhang, X.-Y., Wang, J., Li, D.-H., Guo, Y.-Q., Li, Z.-L. and Hua, H.-M. (2017) Bioactive Terpenoids from Silybum marianum and Their Suppression on NO Release in LPS-Induced BV-2 Cells and Interaction with iNOS. Bioorganic \& Medicinal Chemistry Letters, 27, 2161-2165. https://doi.org/10.1016/j.bmcl.2017.03.058

[32] Mmin, H.J., Hyun, S.K., Sangdoo, A., Cheong, T.K., Mu, H.J., Yong, H.Y., Young, K.K. and Jong, H.O. (2000) Complete Assignment of the $1 \mathrm{H}$ and ${ }^{13} \mathrm{C}$ NMR Spectra of a Sucrose Ester from Euphorbia lathyris L. Journal of Korean Society of Magneetic Resonance in Medicine, 4, 125-132.

[33] Patwardhan, S.A. and Gupta, A.S. (1983) Aromatic Monoterpenes from Lavandula gibsonii. Phytochemistry, 22, 2080-2081.

https://doi.org/10.1016/0031-9422(83)80050-8

[34] Agrawal, P.K. (1992) NMR Spectroscopy in the Structural Elucidation of Oligosacarides and Glycosides. Phytochemistry, 31, 3307-3330. https://doi.org/10.1016/0031-9422(92)83678-R

[35] Horie, T., Tsukayama, M., Yamada, T., Miura, I. and Nakayam, M. (1986) Three Flavone Glycosides from Citrus sudachi. Phytochemistry, 25, 2621-2624. https://doi.org/10.1016/S0031-9422(00)84522-7

[36] Majdi, M., Mashhady, A.M., Maroufi, A. and Crocoll, C. (2017) Tissue-Specific Gene-Expression Patterns of Genes Associated with Thymol/Carvacrol Biosynthesis in Thyme (Thymus vulgaris L.) and Their Differential Changes upon Treatment with Abiotic Elicitors. Plant Physiology and Biochemistry, 115, 152-162.

[37] Da Silva, J.O., Fernandes, R.S., Ticlia, F.K., Oliveira, C.Z., Mazzia, M.V., Francoa, J.J., Giuliattib, S., Pereirac, P.S., Soaresa, A.M. and Sampaioa, S.V. (2007) Triterpenoid Saponins, New Metalloprotease Snake Venom Inhibitors Isolated from Pentaclethra macroloba. Toxicon, 50, 283-291. https://doi.org/10.1016/j.toxicon.2007.03.024

[38] Pertuit, D., Kapundu, M., Mitaine-Offer, A.-C., Miyamoto, T., Tanaka, C., Delaude, C. and Lacaille-Dubois, M.-A. (2019) Triterpenoid Saponins from the Stem Bark of Pentaclethra eetveldeana. Natural Products Communications, 14, 1-5. https://doi.org/10.1177/1934578X19863947

[39] Babady, B. and Hertz, W. (1996) Triterpenes and 1-( $\omega$-Hydroxyceratyl)glycerols from Pentaclethra eetveldeana Root Bark. Phytochemistry, 42, 501-504. https://doi.org/10.1016/0031-9422(95)00944-2

[40] Leal, I.C.R., Júnior, I.I., Pereira, E.M., Laport, M.S., Kuster, R.M. and dos Santos, K.R.N. (2011) Pentaclethra macroloba Tannins Fractions Active against Methicillin-Resistant Staphylococcal and Gram-Negative Strains Showing Selective Toxicity. Brazilian Journal of Pharmacognosy, 21, 991-999. https://doi.org/10.1590/S0102-695X2011005000132

[41] Nnennaya, C.C., Sunday, G.A. and Ahmadou, A.A. (2017) Chemical Constituents from the Sterm Bark of Pentaclethra macrophylla Benth. Nigeria Journal of Pharmaceutical Research, 13, 37-44.

[42] Teixeira, G.L., Maciel, L.G., Mazzutti, S., Gonçalves, C.B., Ferreira, S.R.S. and Block, 
J.M. (2020) Composition, Thermal Behavior and Antioxidant Activity of Pracaxi (Pentaclethra macroloba) Seed Oil Obtained by Supercritical $\mathrm{CO}_{2}$. Biocatalysis and Agricultural Biotechnology, 24, 101521.

https://doi.org/10.1016/j.bcab.2020.101521

[43] Guimarães, A.L.A., Cunha, E.A., Garcia, P.G., Donopoulos, P., Swikidisa, R., Pinheino, V.A. and Nogueira, R.J.L. (2016) Antimicrobial Activity of Copaiba (Copaifera officinalis) and Pracaxi (Pentaclethra macroloba) Oils against Staphylococcus aureus. Importance in Compounding for Wound Care. International Journal of Pharmaceutical Compounding, 20, 58-62.

[44] Mbadiwe, E.I. (1973) Caffeoylputrescine from Pentaclethra macrophylla. Phytochemistry, 12, 2546. https://doi.org/10.1016/0031-9422(73)80479-0

[45] Chen, D., Shao, Q., Yin, L., Younis, A. and Zheng, B. (2019) Polyamine Function in Plants: Metabolism, Regulation on Development, and Roles in Abiotic Stress Responses. Frontiers in Plant Science, 9, 1945. https://doi.org/10.3389/fpls.2018.01945 